\title{
THE RELATION BETWEEN GENDER AND DIFFERENCES IN EMOTIONAL INTELLIGENCE OF FEMALE MANAGERS IN MODERN RURAL TOURISM
}

\author{
Milica Čolovićl ${ }^{1}$ Gordana Nikić2 ${ }^{2}$ Milan Stamatović ${ }^{3}$ \\ *Corresponding authorE-mail: mcolovic@singidunum.ac.rs
}

\author{
A R T I C LE IN F O \\ Original Article \\ Received: 14 November 2020 \\ Accepted: 27 February 2021 \\ doi:10.5937/ekoPolj2101069C \\ UDC 316.346.2- \\ 055.2:796.075]:338.48-44(1-22)
}

\section{Keywords:}

rural tourism, emotional intelligence, gender differences in emotional inteligence and competencies of managers, tourism and hospitality

JEL: Z3

\begin{abstract}
A B S T R A C T
The main goal of this research is to examine the relation between gender and differences in affective attachment, emotional intelligence and self-esteem among students population. The scales for self-assessment of emotional intelligence, affective attachment and self-esteem were used in the current research. The sample consisted of 231 respondents, students of tourism and hospitality management, 71 males and 160 females. Considering that our sample is not representative, because there is a large disproportion in the number of male and female respondents, and that distribution of scores on measured variables deviates from normal, we used nonparametric techniques: Mann-Whitney U test and Kruskal-Walis oneway analysis of variance. The results show that female students have more pronounced emotional intelligence in the domain of perceiving and understanding emotions, as well as a better ability to regulate and manage emotions compared to male respondents, while the measured scores at scale of affective attachment and self-esteem did not show statistically significant differences between gender. On further, female managers in our research see the development of rural tourism as their business opportunity.
\end{abstract}

(C) 2021 EA. All rights reserved.

1 Milica Čolović Ph.D., Assistant Professor, Singidunum University, Danijelova 32, 11.000 Beograd, Phone: +381 6427840 78, E-mail: mcolovic@singidunum.ac.rs, ORCID ID (https:// orcid.org/0000-0002-8393-2158)

2 Gordana Nikić, Ph.D., Associate Professor, Singidunum University, Danijelova 32, 11.000 Beograd, Phone: +381 637365 817, E-mail: gnikic@singidunum.ac.rs, ORCID ID (https:// orcid.org/0000-0003-4349-6539)

3 Milan Stamatović, Ph.D., Full Professor, Principal Research Fellow, University` Union Nikola Tesla', 11000 Beograd, Knez Mihajlova 33, Phone: +381 638736 229, E-mail: prof. milanstamatovic@gmail.com, ORCID ID (https://orcid.org/0000-0003-0471-6447) 


\section{Introduction}

One of the important resources for the development of the tourism industry in Serbia is rural tourism. There is a need to implement a policy of sustainable tourism development due to diversity of natural resources, but also the traditional hospitality and diligence of the rural population that sees the opportunity to restore their farms and construct modern rural tourist facilities. There is also a need to educate and train staff which will be able to participate in this important project. In the preliminary interview conducted for the purpose of this research, a larger number of students stated that they see their business chance in the realization of projects in the field of rural tourism. Previous experiences shows that, in addition to professional knowledge, it is absolutely necessary to develop additional competencies, primarily emotional and social, for future professionals in the field of rural tourism.

The development of rural tourism has been recognized as a business opportunity by the Republic of Serbia, which is trying to rapidly develop this neglected industry with non-refundable financial subsidies (IPARD projects). Also, it can be good support the development of local entrepreneurship and household income (Chivu, 2019; Chivu et al., 2015). The first results are encouraging, considering that in a short period of time, tourist farms are springing up, wineries, agricultural cooperatives, modern tourist facilities are opening, and villages are starting to live. One of the resources for the development of the tourist economy in Serbia is rural tourism. The diversity of natural resources (more than 400 natural assets have been protected so far), but also the nurturing of hospitality in rural households that provide comfortable accommodation in ethnic houses, tradition, folklore, gastronomic tradition, are only part of the resources that this industry can offer. It is necessary to implement a policy of sustainable development of rural tourism in the future, adequate infrastructure, legislation, finances, application of international standards, raising environmental awareness of the population, but we also emphasize the education of staff who can respond to the growing interests of domestic and foreign tourists. In the preliminary interview conducted for the purposes of this research, a large number of surveyed students see their business chance in the implementation of projects in the field of rural tourism.

The time when rural tourism provided additional income to households through the sale of agricultural products, as well as the placement of home-made products, should be viewed as a thing of the past. New trends in sustainable tourism set new standards in order to meet the needs of tourists for authentic experience, spiritual and cognitive nature, but also for rest, recreation, learning, adventure and connecting with the local population (Dašić et al., 2020). In that direction, the initiative of students, future male and female managers for training, not only in the field of professional competencies, but also in the field of additional communication skills, teamwork and development of emotional competencies in working with potential customers should be followed, in order to meet modern market needs. 
Modern organizations in tourism and hospitality are increasingly looking for employees who can work efficiently and maintain assertive communication with clients in the most efficient way, which requires emotional intelligence skills. It is well known that the damage that can be caused by a dissatisfied customer in tourism and hospitality can greatly outweigh the benefits of a satisfied customer.

Although there are many studies that examine emotional intelligence but only few explore the emotional competencies of future managers in the field of tourism and hospitality, especially in rural tourism.

Emotional competencies are important for hospitality and tourism for two key reasons. In the first place, these competencies are necessary to provide a high level of customer service. Service delivery usually takes place in intense social environment, with numerous interpersonal interactions, so it is important that service providers understand the emotions of their customers. Second, managers are expected, not only to provide better service, but also to work well and cooperate successfully with other employees. The ability of managers to plaine, form and build a strong team that is motivated to do their best, whether in the kitchen, dining room or at the reception, largely depends on their emotional intelligence (Kernbach et al, 2004; Savić \& Obradović 2020).

Emotional intelligence has been shown to be positively correlated with job satisfaction and employee performance, especially in food-related jobs (Sy et al., 2019). Success in business largely depends on the persistence, passion, dedication and good interpersonal relationships which can be linked to emotional competence (Lopez-Zafra et al., 2012). Numerous studies have shown that there is a strong correlation between the overall level of emotional intelligence of the service provider and customer satisfaction (Kernbach $\&$ Schutte, 2005; Koc, 2019). In practice, the trend of creating innovative programs and developing highly emotionally intelligent managers in order to achieve better results of employees, is becoming increasingly popular (Altındağ \& Kösedağ1, 2015; Mihailović, et al., 2015; Pantić et al., 2020).

In previous studies, gender differences were obtained when it comes to measuring emotional intelligence. Employed women have been shown to be more likely to interact emotionally with other employees and to have higher scores in emotional competencies than men. Likewise, it has been shown that women are more aware of their emotions compared to men, that they are more empathetic and socially responsible than men. On the other hand, men better cope with stressful situations and have greater selfconfidence compared to women (Baron-Cohen, 2003; Hall \& Mast, 2008).

A study by Maiers-Levi, \& Loken found that women have greater abilities in terms of quality of service in tourism and hospitality given the characteristics of reliability, caution, empathy, and responsibility (Meyers-Levy \& Loken, 2015). As women can be patient and conscientious, they may be able to affirm reliability in the work environment. The results of the research show that women more often express positive emotions tan men (Koc, 2019). 
Despite numerous studies, it is very difficult and ungrateful to compare the obtaining results so far for several reasons. Besides, additional caution is needed regarding given generalization wich some research suggests, that stereotypes about the behavior of men and women may influence the measurement of emotional intelligence (Lopez-Zafra \& Gartzia, 2014).

For the purposes of this paper, the Emotional Competence Questionnaire (Takšić et al., 2006) constructed according to the model of Mayer and Salovey (1990) was used in order to assess these three aspects of emotional intelligence:

1) the ability to perceive and understand emotions,

2) the ability to express and naming emotions and

3) ability to control and manage emotions.

Emotional intelligence is the ability to perceive, understand, manage, control and direct one's own emotions, as well as the emotions of other people (Чоловић \& Златановић, 2011; Милошевић \& Чоловић, 2019). It could be defined as the ability to perceive and express emotions quickly, the ability to recognize and generate feelings that interfire and facilitate thinking, the ability to understand emotions and be awere of them, and the ability to regulate emotions in order to promote emotional and intellectual development (Mayer et al., 2002).

The ability of an individuals to recognize their own or someone else's feelings refers to their ability to perceive emotions and understand the inner experience of emotions, as well as non-verbal gestures, facial expressions and a whole range of indicators, since the fact that emotions are less often expressed in words (Grobova et al., 2017; Gorbova et al., 2019).

Understanding emotions is related to understanding and predicting what will happen while a person is curently expressing certain emotions and how other people will react to them. Expressing emotions and their adequatly nomination is the ability to express emotion verbally and non-verbally as well as to determine it linguistically. Understanding and expressing emotions are very important for harmonious emotional functioning.

Adequate emotion management involves accepting emotions instead of suppressing them and using them for the purpose of making a more meaningful decisions. Emotional intelligence does not function independently but is closely linked with mental processes and behavior of individuals, as well as the psychological traits and character of the individual (Takšić et al., 2006).

Styles of attachment are important not only for understanding the close relationships but also for work behavior, considering that a large part of the work, especially among managers and in the helping professions, takes place in a social context. The concept of affective attachment was first introduced into science by the English psychoanalyst John Bolby (Bolby, 1969/1982), and the theory of affective attachment became the dominant theory of 
emotional personality development, thanks to numerous empirical findings. Initially, this theory exclusively dealt with the child/parent relationship, as well as close relationships, but in recent years, researchers have become more interested in applying the mentioned theory of affective attachment also to the sphere of business. Affective attachment means a specific, asymmetrical relationship that is formed between mother and child in early childhood and lasts throughout life. But even in adulthood, human beings need to be bonded, and in order of that, they are seeking to provide security in relationships.

Numerous studies point to the validity of this theory which come to understanding of work behavior especially when it comes to: job burnout (Leiter et al., 2015), the communication strategy, assessing and developing capacity for leadership (Berson \& Yammarino, 2006; Popper \& Amit, 2009; Davidovitz et al., 2007), job satisfaction (Ronen \& Mikulincer, 2011), etc.

Generally affective attachment styles could be used and they are often use in understanding individual differences in relation toward the environment and to oneself.

Thus, Secure individuals have high self-confidence, a positive attitude towards others, and a high intimacy in relationships given that they have a positive model of themselves and a positive model of others.

Preoccupied (Anxious-preoccupied) individuals show a preoccupation with relationships, have a fear of separation and loneliness and a great need for intimacy. Their model of themselves is negative, while the model of others is positive.

People with Dismissive-avoidant (rejective) style of affective attachment avoid intimacy with others because of negative expectations, maintain a sense of self-worth through compulsive self-confidence. Their model of themself is positive, the model of another is negative.

Fearful-avoidant style characterized by low self-confidence, lack of confidence in themselves and others. They avoid intimacy for fear of rejection and injury. They have both negative model - of themselves and others.

According to Hazan and Shaver, who used a three-category model to explain affective attachment, job security is shown through a secure orientation towards work, a higher degree of success, job satisfaction, and rewards. Anxious/ambivalent individuals use work as an instrument to gain praise, avoid feelings of underestimation, satisfy the need to please others, etc. People with avoidant style prefer to work alone, it is very difficult for them to interrupt obligations, they are very nervousness when they are not working. Generally, for them work is an justified excuse to avoid socialization, which often has a very negative effect on their health (Hazan \& Shaver, 1990).

For the purposes of this paper, we were interested in the global self-esteem of individuals which we investigated by measuring positive and negative feelings that they have about themselves. 
According to Rosenberg, self-esteem is a set of thoughts and feelings about one's own value and significance, a global attitude that a person has towards ownself as a whole person (Rosenberg, 1979). Rosenberg argues that self-esteem is formed on the basis of feedback that a child receives, during growing up process, from parents, teachers, peers, therapists and other important people around him and that it is reflected as a positive or negative attitude about himself.

Bearing in mind the numerous stereotypes about lower self-esteem among women at work, we were interested in whether these differences will be shown in our sample as well.

\section{Material and metods}

In a preliminary interview conducted for the purposes of this research, it was shown that there is an interest of students, especially future female managers, in the design and implementation of projects in the field of sustainable rural tourism.

The main goal of this research is to examine the relation between gender and differences in affective attachment, emotional intelligence and self-esteem among students population.

\section{Hypothesis}

There are gender differences in emotional intelligence, affective attachment, and selfesteem between the examined students.

\section{Sample}

In forming the sample, special attention was paid to provide approximately the same number of male and female respondents. However, our sample was suitable type and only partially met these conditions. It consisted of 231 respondents (160 females and 71 males), with an average age of 22 years. It included future managers, students from tourism and hospitality, from three different cities: Belgrade (128), Bijeljina (40) and Nis (63).

\section{Instruments and variables}

The SM-ECR-R scale (Faria \& Lima Santos, 2000; adaptation by Hanak \& Dimitrijević, 2013) was used in the study to assess the affective attachment of the subjects. It is a Serbian version of Experiences in Close Relationships (ECR), revised to measure affective attachment in general. More precisely, the SM-ECR-R Scale was created to measure individual differences in affective attachment in terms of two dimensions: anxiety (fear of rejection and abandonment) and avoidance (discomfort due to closeness and dependence on others). It contains of 36 items, of which one half refers to anxiety and the other to avoidance. According to the authors it is a reliable and valid scale, although its internal structure and consistency can vary in different patterns, depending on age, education, gender and culture. On our sample both subscales have a high internal consistency: $\alpha=.87$ and $\omega=.89$ for anxiety and $\alpha=$ and $\omega=.88$ for avoidance. 
For the purposes of this paper, the Questionnaire for Emotional Competence (Takšić et al., 2006) was constructed, in accordance to Mayer and Salovey model, which assesses three aspects of emotional intelligence:
1) ability to observe and understand emotions
2) the ability to express and name emotions
3) ability to manage emotions

All three scales have satisfactory reliability on different samples, from $\alpha=0.71$ to $\alpha$ $=0.90$. The Emotional Competence Questionnaire (UEK-45) has been translated and validated in several countries: Slovenia (Avsec, 2005), Spain (Extremera \& FernándezBerrocal, 2005), Portugal (Faria \& Lima Santos, 2005), Sweden (Molander et al., 2005), Finland (Räty, 2005) and Japan (Toyota, 2005). Metric characteristics of the mentioned questionnaire was at a satisfactory, statistical significant, level in all of these countries.

The Rosenberg Self-Esteem Scale (RSE) research also used the (Rosenberg, 1979). The scale is one-dimensional and measures the global self-esteem or general value orientation of an individual towards oneself. The scale has 10 items, five in the negative and five in the positive direction. Subjects were asked to mark on a five-point Likert scale assessment to what extent the claims are related or not related to them. The score range is from 0 to 40 . A higher score means a higher degree of self-esteem.

\section{Results}

Gender differences in emotional intelligence, types of affective attachment and selfesteem were checked by t-test for independent samples in which the grouping variable was the gender of the subjects, while the set of dependent variables consisted of scores on subscales of emotional intelligence, affective attachment and self-esteem scale.

Table 1. Statistical significance of

Mann-Whitney $\mathrm{U}$ test for emotional inteligence

\begin{tabular}{|c|c|c|c|}
\hline \multicolumn{4}{|c|}{ EMOTIONAL INTELIGENCE } \\
\hline \multirow{2}{*}{ Mann-Whitney U } & URE & IIE & UE \\
\cline { 2 - 4 } & 4175.500 & 5000.000 & 4763.500 \\
\hline Sig. & $.001^{*}$ & .146 &. $.047^{*}$ \\
\hline
\end{tabular}

Source: Work of authors based on reserch Čolović, Nikić, Stamatović, 2020

Based on the results of Mann-Whitney U test, gender differences in Emotional intelligence are at statistical significant level on 2 subscales: URE-Observation and understanding of emotions $(\mathrm{U}=4175.500 ; \mathrm{p}<0,01)$ and $U E-$ Ability to regulate and manage emotions $(\mathrm{U}=-4763.500 ; \mathrm{p}<0,05)$. The obtained gender differences in emotional inteligence at the second registred subscale IIE - the ability to express and name emotions are no at the statistically significant level $(\mathrm{U}=-5000.000 ; \mathrm{p}>0,05)$ (Table 1).

Both significant differences are in favor of female respondents, so it could be said that, women have significantly more pronounced emotional intelligence in the domain 
of perceiving and understanding emotions $(M R=125.40)$, than men $(M R=94.81)$, as well as, better ability to regulate and manage emotions $(\mathrm{MR}=121.73)$, than men $(\mathrm{MR}=103.09)$ (Table 2).

Table 2. Gender differences in emotional intelligence

\begin{tabular}{|c|l|c|c|c|}
\hline EMOTIONAL INTELIGENCE & Gender & $\mathbf{N}$ & $\mathbf{M R}$ & $\sum \mathbf{R}$ \\
\hline \multirow{3}{*}{ URE } & Male & 71 & 94.81 & 6731.50 \\
\cline { 2 - 5 } & Female & 160 & 125.40 & 20064.50 \\
\cline { 2 - 5 } & Total & 231 & & \\
\hline \multirow{3}{*}{ IIE } & Male & 71 & 106.42 & 7556.00 \\
\cline { 2 - 5 } & Female & 160 & 120.25 & 19240.00 \\
\cline { 2 - 5 } & Total & 231 & & \\
\hline \multirow{3}{*}{ UE } & Male & 71 & 103.09 & 7319.50 \\
\cline { 2 - 5 } & Female & 160 & 121.73 & 19476.50 \\
\cline { 2 - 5 } & Total & 231 & & \\
\hline
\end{tabular}

Source: Work of authors based on reserch Čolović, Nikić, Stamatović, 2020

When it comes to the style of affective attachment the results show that men, on average, have a slightly more pronounced fearful and rejecting style of affective attachment, while the safe and preoccupied type is almost the same for both groups of resspondents (Table 3).

Table 3. Gender differences in affective attachment style

\begin{tabular}{|c|c|c|c|c|}
\hline $\begin{array}{c}\text { AFFECTIVEATTACHMENT } \\
\text { STYLE }\end{array}$ & Gender & $\mathbf{N}$ & $\mathbf{M R}$ & $\sum \mathbf{R}$ \\
\hline \multirow{3}{*}{ Secure } & Male & 71 & 121.85 & 8561.00 \\
\cline { 2 - 5 } & Female & 160 & 114.14 & 18377.00 \\
\cline { 2 - 5 } & Total & 231 & & \\
\hline \multirow{3}{*}{ Fearful-avoidant } & Male & 71 & 123.96 & 8801.00 \\
\cline { 2 - 5 } & Female & 160 & 113.21 & 18227.00 \\
\cline { 2 - 5 } & Total & 231 & & \\
\hline \multirow{3}{*}{ Preoccupied } & Male & 71 & 119.45 & 8481.00 \\
\cline { 2 - 5 } & Female & 160 & 115.20 & 18547.00 \\
\cline { 2 - 5 } & Total & 231 & & \\
\hline \multirow{2}{*}{ Dismissive-avoidant } & Male & 71 & 126.73 & 8998.00 \\
\cline { 2 - 5 } & Female & 160 & 111.99 & 18030.00 \\
\cline { 2 - 5 } & Total & 231 & & \\
\hline
\end{tabular}

Source: Work of authors based on reserch Čolović, Nikić, Stamatović, 2020

But obtained differences in scores between male and female are not at the statistical significant level (Table 4).

Table 4. Statistical significance of Mann-Whitney U test for affective attachment style

\begin{tabular}{|c|c|c|c|c|}
\hline \multicolumn{5}{|c|}{ AFFECTIVE ATTACHMENT STYLE } \\
\hline $\begin{array}{c}\text { Mann-Whitney } \\
\text { U }\end{array}$ & Secure attachment & Fearful-avoidant & Preoccupied & Dismissive-avoidant \\
\cline { 2 - 5 } & 5336.000 & 5186.000 & 5506.000 & 4989.000 \\
\hline Sig. & .421 & .261 & .657 & .123 \\
\hline
\end{tabular}

Source: Work of authors based on reserch Čolović, Nikić, Stamatović, 2020 
In the case of self-esteem, the result between male $(\mathrm{MR}=124.30)$ and female $(\mathrm{MR}=119.06)$ is almost equal (Table 5).

Table 5. Gender differences in self-esteem

\begin{tabular}{|l|l|c|c|c|}
\hline \multirow{3}{*}{ SELF-ESTEEM } & Gender & $\mathbf{N}$ & MR & $\sum \mathbf{R}$ \\
\cline { 2 - 6 } & Male & 71 & 124.30 & 8825.00 \\
\cline { 2 - 6 } & Female & 160 & 119.06 & 18203.00 \\
\cline { 2 - 6 } & Total & 231 & & \\
\hline
\end{tabular}

Source: Work of authors based on reserch Čolović, Nikić, Stamatović, 2020

As can be assumed based on the previous result, the size of the obtained differences is not at a statistically significant level (Table 6).

Table 6. Statistical significance of Mann-Whitney U test for self-esteem

\begin{tabular}{|c|c|}
\hline \multirow{2}{*}{ Mann-Whitney U } & SELF-ESTEEM \\
\cline { 2 - 2 } & 5162.000 \\
\hline Sig. & .237 \\
\hline
\end{tabular}

Source: Work of authors based on reserch Čolović, Nikić, Stamatović, 2020

In order to test the differences in the scores of the several groups of respondents on the main variables (emotional intelligence, attachment styles and self-esteem), in this particular case - those who studying in different cities: Belgrade, Nis and Bjeljina (control variable), the Kruskal-Walis one-way analysis of variance test was used.

Table 7. Results of Kruskal Wallis test

\begin{tabular}{|c|c|c|c|c|c|c|c|c|}
\hline & \multicolumn{3}{|c|}{$\begin{array}{l}\text { EMOTIONAL } \\
\text { INTELIGENCE }\end{array}$} & \multicolumn{4}{|c|}{$\begin{array}{l}\text { AFFECTIVE ATTACHMENT } \\
\text { STYLE }\end{array}$} & \multirow{2}{*}{$\begin{array}{c}\text { SELF- } \\
\text { ESTEEM } \\
\text { Self-esteem }\end{array}$} \\
\hline & URE & $I I E$ & $U E$ & Secure & $\begin{array}{l}\text { Fearful- } \\
\text { avoidant }\end{array}$ & Preoccupied & $\begin{array}{l}\text { Dismissive- } \\
\text { avoidant }\end{array}$ & \\
\hline$X^{2}$ & 3.436 & .736 & 4.361 & 8.203 & 8.995 & 7.548 & 8.973 & \\
\hline df & 2 & 2 & 2 & 2 & 2 & 2 & 2 & 2 \\
\hline Sig. & .179 & .692 & .113 & .085 & .079 & .065 & .058 & .655 \\
\hline
\end{tabular}

Source: Work of authors based on reserch Čolović, Nikić, Stamatović, 2020

As can be seen, no statistically significant differences were obtained between groups of students from different cities, when it comes to their emotional intelligence, the attachment style they developed and adopted, as well as, the level of their self-esteem $(\mathrm{p}>0,05)$ (Table 7).

\section{Discussion}

Our analysis showed that women compared to men achieve better results on the two aspects of emotional intelligence: the ability to identify and to understand the emotions and the ability to manage emotions.

This finding is consistent with previous research on emotional intelligence (Ciarrochi et al., 2000, 2005; Day \& Carroll, 2004; Palmer et al., 2005). Mayer and his associates 
found that there are significant gender differences in favor of female respondents (Mayer et al., 2002).

The research of Vučenović and Takšić showed that there are gender differences in the self-assessment of emotional competencies in favor of female respondents (Vučenović, 2009; Takšić et al., 2006).

In the research from 2014 and 2015 (Nikić et al., 2014a, 2015), it was obtained that managers as well as management students have higher scores on all three scales of emotional intelligence. It was shown that respondents with higher scores on emotional intelligence, show greater activity and sociability and lover levels of neuroticism and aggression, which is important for teamwork. It has also been shown that people with high scores on emotional intelligence show less neuroticism and greater sociability (Nikić et al., 2014b).

Regarding gender differences and emotional intelligence, one should often been consider - research that measures different dimensions of emotional intelligence. It has been shown that women are more aware of their emotions than men, they are more empathetic and socially responsible than men, but it has also been shown that men cope better with stressful situations and have greater self-confidence than women (BaronCohen, 2003; Hall \& Mast, 2008).

Regarding the difference between men and women, when it comes to affective attachment, no statistically significant differences were obtained in this study. A number of studies have found that men are more likely to have avoidant attachment style, while the women in general have higher anxiety scores than men. However, in a number of studies, women showed a more pronounced avoidant style of affective attachment, while men were more anxious in relation to female respondents (Scharfe, 2017).

It will be interesting to study those men and women who go "against the rules", for example women with higher avoidance scores and men who are more anxious then women.

In this study, gender differences on the self-esteem scale, were not obtained. The selfesteem scale used in this research and the obtained results do not provide an opportunity for some more reliable conclusions when it comes to the differences between male and female subjects.

Our findings support previous research on gender differences in emotional intelligence (Meyers et al., 2015; Koc, 2019) as female show reliability, patience and positive expression of emotions which can be relevant to work in tourism and hospitality.

Given the results of numerous studies, that shown that women are more competent and have greater interest in the field of emotions, and that they are better prepared and motivated, the question of additional training and affirmation of women for tourism and hospitality, especially in managerial positions, becomes urgent and very significant.

However, one should be also keep in mind, in accordance with the increasingly current social trends, that suggest that men should take more care of their emotions and develop 
higher emotional competencies. As globalization brings many changes, the market is becoming more and more ready and hungry for emotionally literate managers, which is a challenge especially for women in tourism and hospitality to advance their careers.

\section{Conclusion}

In the modern conditions of tourism business, and especially in the field of rural tourism, the important question is how united men and women can achieve high results in working with clients. Researchers' efforts are focused on studying all the factors that affect productivity. On the one hand, it is well known that a manager's strength comes from his/her available power, professional competencies, knowledge, skills, relationships in companies, but on the other hand, the manager's personality as well as his/her emotional and social competencies are crucial. Developing emotional security (low levels of anxiety and avoidance) and emotional intelligence (high ability to perceive and understand emotions, to express and name emotions, and the ability to manage emotions) are key to achieving top results in work, for both, men and women. This research, like many others, gives preference to women's abilities in the field of emotions, but the question remains, how much of these abilities actually use female managers, to achieve better results in tourism and hospitality and how the education system can ensure that its students' competencies improve. One of the assumptions that should, also, be tested is whether current changes in society can affect the emotional intelligence of men in order to improve their competencies in this important field.

The concept of sustainable development of rural tourism brings the establishment of new social values based on knowledge, creativity and human resources. There is a need for education of skilled and professional staff that will help to improve this important activity with respect to the sustainable development strategies that are focused on today but also on the future. Future female managers in our research see the development of rural tourism as their business opportunity.

\section{Conflict of interests}

The authors declare no conflict of interest.

\section{References}

1. Altındağ, E., \& Kösedağı, Y. (2015). The Relationship Between Emotional Intelligence of Managers, Innovative Corporate Culture and Employee Performance. Procedia - Social and Behavioral Sciences, 210, 270-282. https:// doi.org/10.1016/j.sbspro.2015.11.367

2. Avsec, A. (2005). Emotional Skills and Competence Questionnaire: Reliability and validity of a Slovene version at the 9th European Congress of Psychology (3-8 July), Granada, Spain.

3. Baron-Cohen, S. (2003). The essential difference: the truth about the male and female brain. New York, Basic Book. 
4. Berson, Y., \& Yammarino, O. (2006). Attachment style and individual differences in leadership perceptions and emergence. Journal of Social Psychology, 146(2), 165-182. https://doi.org/10.3200/SOCP.146.2.165-182

5. Bowlby, J. (1969/1982). Attachment and loss: Vol. 1. Attachment. 2. New York, Basic Books.

6. Chivu, L., Ciutacu, C., \& Georgescu, L. (2015). Household income in Romania. A challenge to economic and social cohesion. Procedia Economics and Finance, 22, 398-401. https://doi: 10.1016/S2212-5671(15)00310-X

7. Chivu, L. (2019). Local entrepreneurship and social services in Romania. Territorial analysis. European Research on Management and Business Economics, 25(2), 7986. https://doi.org/10.1016/j.iedeen.2019.04.001

8. Čolović, M., \& Zlatanović, Lj. (2011). Facial signs of masking, blocking and suppressing experimentally induced emotions of sadness. Yearbook of Psychology, $8(10), 152-168$.

9. Ciarrochi, J.V., Chan, A.Y.C., \& Caputi, P. (2000). A critical evaluation of the emotional intelligence construct. Personality and Individual Differences, 28(3), 539-561. https://doi.org/10.1016/S0191-8869(99)00119-1

10. Ciarrochi, J.V., Hynes, K., \& Crittenden, N. (2005). Can men do better if they try harder? Gender and motivational effects on emotional awareness. Cognition and Emotion, 19, 133-141. https://doi.org/10.1080/02699930441000102

11. Day, A.L., \& Carroll, S.A. (2004). Using an ability-based measure of emotional intelligence to predict individual performance, group performance, and group citizenship behaviours. Personality and Individual Differences, 36(6), 1443-1458. 10.1016/S0191-8869(03)00240-X

12. Dašić, D., Živković, D., \& Vujić, T. (2020). Rural tourism in development function of rural areas in serbia. Economics of Agriculture, 67(3), 719-733. https://doi. org/10.5937/ekoPolj2003719D

13. Davidovitz, R., Mikulincer, M., Shaver, P.R., Izsak, R., \& Popper, M. (2007). Leaders as attachment figures: Leaders' attachment orientations predict leadershiprelated mental representations and followers' performance and mental health. Journal of Personality and Social Psychology, 93(4), 632-650. https://doi. org/10.1037/0022-3514.93.4.632

14. Extremera, N. \& Fernández-Berrocal, P. (2005). Emotional Skills and Competence Questionnaire (ESCQ): Adaptation to Spanish, reliability and its relationship with well-being indexes. In V. Takšić (Chair), Cross-cultural validation of Emotional Skills and Competence Questionnaire (ESCQ). Symposium conducted at the 9th European Congress of Psychology, Granada, Spain. 
15. Faria, L., \& Lima Santos, N. (2005). Adaptation of the Emotional Skills and Competence Questionnaire (ESCQ) to the Portuguese context. In V. Takšić (Chair), Cross-cultural validation of Emotional Skills and Competence Questionnaire (ESCQ). Symposium conducted at the 9th European Congress of Psychology, Granada, Spain.

16. Grobova, J., Čolović, M., Marjanović-Jakovljević, M., Njeguš, A., Demirel, H., \& Gholamreza, A. (2017). Automatic Hidden Sadness Detection Using MicroExpressions. Proceedings Paper of 12th IEEE International Conference on Automatic Face \& Gesture Recognition (FG 2017), 828 - 832.

17. Gorbova, J., Čolović, M., Marjanović-Jakovljević, M., Njeguš, A., \& Anbarjafari, G. (2019). Going Deeper in Hidden Sadness Recognition Using Spontaneous Database. Multimedia tools and applications, 78(16), 23161 - 23178.

18. Hall, J.A., \& Mast, M.S. (2008). Are women always more interpersonally sensitive than men? Impact of goals and content domain. Personality and Social Psychology Bulletin, 34(1), 144-155. https://doi.org/10.1177/0146167207309192

19. Hanak, N., \& Dimitrijevic, A. (2013). A Serbian version of modified and revised experiences in close relationships scale (SM-ECR-R). Journal of Personality Assessment, 95(5), 530-538. https://doi.org/10.1080/00223891.2013.778271

20. Hazan, C., \& Shaver, P.R. (1990). Love and work: An attachment-theoretical perspective. Journal of Personality and Social Psychology, 59(2), 270-280. https://doi.org/10.1037/0022-3514.59.2.270

21. Kernbach, S., Schutte, N. \& Langhorn, S. (2004). How emotional intelligence can improve management performance. Intern ational Journal of Contemporary Hospitality Management, 16(4), 220-230. https://doi. org/10.1108/09596110410537379

22. Kernbach, S., \& Schutte, N.S. (2005). The impact of service provider emotional intelligence on customer satisfaction. The Journal of Services Marketing, 19(7), 438-444. https://doi.org/10.1108/08876040510625945

23. Koc, E. (2019). Emotional Intelligence in Tourism and Hospitality, Turkey: Bandirma Onyedi Eylul University.

24. Leiter, M.P., Day, A., \& Price, L. (2015). Attachment styles at work: measurement, collegial relationships, and burnout. Burnout research, 2(1), 25-35. https:/doi. org/10.1016/j.burn.2015.02.003

25. Lopez-Zafra, E., Garcia-Retamero, R., \& Martos, M.P.B. (2012). The Relationship Between Transformational Leadership and Emotional Intelligence from a Gendered Approach. Psychological Record, 62(1), 97-114.

26. Lopez-Zafra, E., \& Gartzia, L. (2014). Perceptions of Gender Differences in SelfReport Measures of Emotional Intelligence. Sex Roles: A Journal of Research, 70(11-12), 479-495. https://doi.org/10.1007/s11199-014-0368-6 
27. Mayer, J. D. \& Salovey, P. (1990). Emotional intelligence, Imagination, Congition and Personality. Imagination, Cognition, and Personality, 9, 185-211.

28. Mayer, J.D., Caruso, D.R., \& Salovey, P. (1999). Emotional intelligence meets traditional standards for an intelligence. Intelligence, 27(4), 267-298. https://doi. org/10.1016/S0160-2896(99)00016-1

29. Mayer, J. D., Salovey, P., \& Caruso, D. R. (2002). Mayer-Salovey-Caruso Emotional Intelligence Test (MSCEIT): User's manual. Toronto, Canada: MultiHealth Systems.

30. Meyers-Levy, J., \& Loken, B. (2015). Revisiting gender differences: What we know and what lies ahead (Review). Journal of Consumer Psychology, 25(1), 129149. https://doi.org/10.1016/j.jcps.2014.06.003

31. Mihailović, B., Cvijanović, D., \& Simonović, Z. (2015). The role of business ethics in human resource management, Institute of Agricultural Economics, 65(1), 85-96. https://doi.org/10.5937/ekonomika1501085M

32. Milošević, M., \& Čolović, M. (2019). Razvojna i pedagoška psihologija sa primenom u sportu i fizičkom vaspitanju, Beograd: Univerzitet Singidunum. [in English: Developmental and pedagogical psychology with application in sports and physical education, Belgrade: Singidunum University].

33. Molander, B., Holmström, S., \& Jansson, J. (2005). ESCQ-45 as related to selfrated job stress and health. Proceedings Paper at the 9 th European Congress of Psychology, Granada, Spain.

34. Nikić, G., Mitrović, M., \& Travica, V. (2014a). The quality of business communications depending on the attachment style, social emotional competences and personality traits. Industrija, 42(4), 79-97.

35. Nikić, G., Travica, V., \& Mitrović, M. (2014b). Differences between employees and managers regarding socio-emotional competences. Serbian Journal of Management, 9(2), 281-292. https://doi.org/10.5937/sjm9-5440

36. Nikić, G., \& Mitrović, M. (2015). Emotional intelligence of the employees in Serbia - gender differences. Journal of Women's Entrepreneurship and Education $-J W E, 67-85$.

37. Palmer, B.R., Gignac, G., Monocha, R., \& Stough, C. (2005). A psychometric evaluation of the Mayer-Salovey-Caruso Emotional Intelligence Test version 2.0. Intelligence, 33(3), 285-305. https://doi.org/10.1016/j.intell.2004.11.003

38. Pantić, N., Milojević, I., \& Mićović, A. (2020). Menadžerska analiza mogućnosti upravljanja procesom privatizacije. Tehnika, 75(4), 493-497. https:/doi. org/10.5937/tehnika2004493P

39. Popper, M., \& Amit, K. (2009). Influence of Attachment Styile on Major Psychological capacites to Lead. The Journal of Genetic Psychology, 170(3), 244267. https://doi.org/10.1080/00221320903218307 
40. Räty, H. (2005). Perceived emotional competence and self-concept. Proceedings Paper at the 9th European Congress of Psychology, Granada, Spain.

41. Ronen, S. \& Mikulincer, M. (2011). Predicting employees'satisfaction and burnout from managers' attachment and caregiving orientations, 828-849.

42. Rosenberg, M. (1979). Conceiving the Self. New York: Basic Books.

43. Savić, B., \& Obradović, N. (2020). Challenges in financial reporting about biological assets. Oditor-časopis za menadžment, finansije i pravo, 6(1), 7-21. https://doi.org/10.5937/Oditor2001007S

44. Scharfe, E. (2017). Sex Difference in Attachment. In T. K. Shackelford \& V. A. Weekes-Shackelford (Eds.), Encyclopedia of Evolutionary Psychological Science. Springer International Publishing. https:/doi.org/10.1007/978-3-319-169996_3592-1

45. Sy, T., Tram, S., \& O’Hara, L.A. (2006). Relation of employee and manager emotional intelligence to job satisfaction and performance. Journal of Vocational Behavior, 68(3), 461-473. https://doi.org/10.1016/j.jvb.2005.10.003

46. Takšić, V., \& Moharić, T., \& Munjas, R. (2006). Emocionalna inteligencija: teorija, operacionalizacija, primjena $i$ povezanost $s$ pozitivnom psihologijom. Rijeka: Filozofski fakultet. [in English: Emotional intelligence: theory, operationalization, application and connection with positive psychology. Rijeka: Faculty of Philosophy].

47. Toyota, H. (2005). Emotional Skills and Competence Questionnaire: Development of a Japanese version Proceedings Paper 9 th European Congress of Psychology, Granada, Spain.

48. Vučenović, D., Hajncl, Lj., \& Takšić, V. (2014). Razvoj emocionalne inteligencije u obiteljskom okruženju i odnos s problemima u ponašanju. Poglavlje u knjizi: Psihološki aspekti suvremene obitelji, braka i partnerstva, Sveučilišni udžbenik, Zagreb, Naklada Slap i HPD, 275 — 296. [in English: Development of emotional intelligence in a family environment and relationship with behavioral problems. Chapter in the book: Psychological aspects of the modern family, marriage and partnership, University textbook, Zagreb, Naklada Slap and HPD, 275 - 296]. 